\title{
PELATIHAN DAN PEMAHAMAN PEMASARAN PRODUK MENUJU ENTREPRENUER MUDA YANG KREATIF DAN INOVATIF KEPADA KARANG TARUNA RW 11 KEL. PENGASINAN, DEPOK, JAWA BARAT
}

\author{
Lismiatun $^{1}$, Ana Septiana Rahman ${ }^{2}$, Abdul Azis ${ }^{3}$, Nindie Ellesia ${ }^{4}$ \\ Universitas Pamulang \\ dosen01460@unpam.ac.id
}

\begin{abstract}
The purpose of Community Service Activities is to carry out one of the Tri Dharma of Higher Education. Besides, Karang Taruna $R W 11$ as a young generation can be useful and help all Government Programs for the surrounding community, especially in empowering the active entrepreneurial members in developing regional potential, especially in the community of $R W 11$ and Higher Education can make a major contribution to the development and application of science to the community. The activity method used was that we surveyed by visiting the location and conducting interviews and observations with members of the Karang Taruna RW 11, Kel. Pengasinan, Kota Depok, Jawa Barat. The results of community service obtained are increased knowledge and experience of members of the Karang Taruna $R W 11$ who so far are still minimal about marketing, promotion, financial management, supply chain, inventory, and the use of digital technology so that they have a better view of the importance of improving their knowledge as entrepreneurs or entrepreneurs, also to become qualified human resources to enter the world of work because and how important it is to improve their quality to face market competition global.
\end{abstract}

\section{Keywords: entrepreneur, marketing, technology}

\begin{abstract}
ABSTRAK
Tujuan dari Kegiatan Pengabdian Kepada Masyarakat adalah untuk melaksanakan salah satu Tri Dharma Perguruan Tinggi. Selain itu agar Karang Taruna RW 11 sebagai generasi muda dapat bermanfaat dan membantu semua Program Pemerintah untuk masyarakat sekitar terutama dalam memberdayakan keaktifan anggotanya berwirausaha mengembangkan potensi wilayah terutama di lingkungan masyarakat RW 11 serta Perguruan Tinggi dapat memberikan kontribusi besar kepada pengembangan dan penerapan keilmuan kepada masyarakat. Metode kegiatan yang digunakan adalah kami melakukan survey dengan mendatangi lokasi serta melakukan wawancara dan observasi kepada anggota Karang Taruna Rw 11, Kelurahan Pengasinan, Kota Depok, Jawa Barat. Hasil pengabdian masyarakat yang diperoleh adalah bertambahnya keilmuan dan pengalaman para anggota Karang Taruna Rw 11 yang selama ini masih minim tentang pemasaran, promosi, manajemen keuangan, supply chain,
\end{abstract}


inventory dan pemanfaatan teknologi digital sehingga mereka memiliki pandangan yang lebih baik lagi tentang pentingnya meningkatkan keilmuan mereka sebagai wirausahawan atau enterepreneur serta mampu menjadi SDM yang berkualitas untuk memasuki dunia kerja karena dan betapa pentingnya meningkatkan kualitas diri mereka untuk menghadapi persaingan pasar global.

Kata Kunci : entreprenuer, marketing, teknologi

\section{A. PENDAHULUAN}

Di era globalisasi sekarang ini, teknologi informasi berperan sangat penting. Dengan menguasai teknologi dan informasi, kita memiliki modal yang cukup untuk menjadi pemenang dalam persaingan global. Informasi merupakan modal utama dalam mengembangkan ilmu pengetahuan dan teknologi yang menjadi senjata pokok untuk membangun negara. Era teknologi adalah masa dimana produk selalu didaur atau dicipta untuk memenuhi kebutuhan manusia. Pada umumnya perusahaan atau pelaku usaha dalam menjalankan kegiatan usahanya tentu berkeinginan untuk membuat produknya laku terjual.

Media digital pun bahkan sudah menjadi gaya hidup modern, di samping itu penggunaan media digital telah banyak membantu setiap orang dalam melakukan rutinitas. Individu, organisasi, bahkan pemerintahan juga tidak pernah terlepas dari aktifitas menggunakan media digital. Fungsi lain dari penggunaan media digital meliputi : branding, sharing, promosi, maupun marketing. Perkembangan teknologi informasi dan internet juga berpengaruh besar terhadap perkembangan di bidang promosi produk. Hal tersebut tentunya sangat menguntungkan bagi dunia promosi produk karena kemudian terjadi peningkatan efektivitas jika dibandingkan dengan media kovensional.

Dewasa ini sudah saatnya pelaku usaha mempersiapkan diri untuk memasuki era baru dalam dunia pemasaran. Sebab selama ini, kelemahan menentukan strategi pemasaran yang efektif dan efisien menjadi persoalan bagi hampir seluruh pelaku usaha di tanah air. Teknologi menawarkan berbagai kemudahan dalam perekonomian yang tentunya sangat menunjang sistem perekonomian yang ada. Salah satunya adalah peranan teknologi dalam perdagangan yang saat ini dikenal dengan E-Commerce. E-Commerce atau perdagangan elektronik atau e-dagang adalah penyebaran, pembelian, penjualan, pemasaran barang dan jasa melalui sistem elektronik seperti internet atau televisi ataupun jaringan internet lainnya.

Kewirausahaan merupakan sebuah proses mengidentifikasi, memodifikasi, mengembangkan suatu produk baru, metode baru dengan cara-cara inovasi atau terobosan baru yang belum pernah di lakukan oleh orang lain sebelumnya baik cara produksi maupun pemasarannya untuk mendapatkan keuntungan atau laba. Menurut Keputusan Menteri Koperasi dan Pembinaan Pengusaha Kecil Nomor 961/KEP/M/XI/1995, kewirausahaan adalah semangat, sikap, perilaku dan kemampuan seseorang dalam menanggani usaha atau kegiatan yang mengarah pada upaya mencari, menciptakan serta menerapkan cara kerja, teknologi dan produk baru dengan meningkatkan efisiensi dalam rangka memberikan pelayanan yang lebih baik dan atau memperoleh keuntungan yang lebih besar.

Wujud dari Kewirausahaan adalah UMKM yang merupakan salah satu bentuk usaha mikro, kecil menengah yang sudah tidak asing lagi di kalangan masyarakat, dimana usaha ini di bentuk dan dikelola berdasarkan inisiatif perseorangan. UMKM juga dapat membantu program kerja pemerintah dalam hal mengurangi angka tingkat pengangguran yang semakin hari semakin tinggi. UMKM telah memberikan kontribusi besar dalam meningkatkan pendapatan daerah maupun pendapatan negara Indonesia yang sudah terbukti saat krisi 
ekonomi tahun 1998 dimana sektor ekonomi Makro banyak bertumbangan namun sektor ekonomi Mikro justru mampu bertahan seperti saat pendemi Covid-19 sekarang ini. UMKM seyogyanya adalah mampu memanfaatkan berbagai Sumber Daya Alam yang ada diwilayah masing-masing dan di olah menjadi sesuatu yang bernilai ekonomis sehingga berguna bagi masyarakat sekitar itu sendiri melalui Lembaga Swadaya Masyarakat seperti Karang Taruna.

Begitu sangat pentingnya memberikan dukungan kepada para anggota Karang Taruna untuk memiliki kompetensi dalam kewirausahaan yang lebih ditekankan pada contoh nyata cara-cara berwirausaha dengan memanfaatkan peluang pasar saat ini dengan strategi menyusun perencanaan, memproduksi, mengemas serta memasarkan dengan cara yang sangat sederhana. Sehingga para anggota dan peserta tersebut nantinya sudah memiliki pondasi jiwa wirausahawan yang mampu menjadi SDM yang unggul dalam menciptakan peluang usaha. Oleh karena itu dengan mempertimbangkan latar belakang yang telah dijelaskan diatas kami berinisiatif untuk membentuk kelompok Pengabdian Kepada Masyarakat bagi para anggota Karang Taruna yang berada di RW 11, Kelurahan Pengasinan, Depok, Jawa Barat khususnya dalam program "Pelatihan dan Pemahaman Dalam Pemasaran Produk Menuju Entreprenuer Muda Yang Kreatif dan Inovatif" dalam mengembangkan usaha UMKM di lingkungan masyarakat sekitar RW 11, Kel. Pengasinan, Kota Depok.

\section{B. METODE PELAKSANAAN KEGIATAN}

Metode pelaksanaan dalam Pengabdian Kepada Masyarakat ini dibagi menjadi 3 (tiga) tahap yaitu tahap awal, tahap pelaksanaan dan tahap akhir. Pada tahap awal dilaksanakan observasi, dan wawancara secara langsung dengan mitra, hal ini bertujuan untuk mengetahui gambaran kondisi mitra dan untuk mengetahui permasalahan atau kendala yang di hadapi oleh para pelaku usaha.

Tahap kedua adalah tahap pelaksanaan berupa pelatihan pembukuan keuangan sederhana, manajemen inventory, teknik promosi dan pemasaran serta teknik komunikasi bisnis yang dapat diaplikasikan oleh pelaku usaha, hal ini bertujuan untuk meningkatkan keterampilan dan pengetahuan mengenai manajemen keuangan usaha agar tidak tercampur antara keuangan keluarga dengan keuangan usaha, melalui pencatatan keuangan pelaku usaha dapat mengetahui perkembangan usahanya.

Tahap yang terakhir adalah tahap monitoring. Pada tahap ini, dilakukan tracking dan monitoring evaluasi dari tahap 2 dimana pemilik UMKM menunjukkan hasil pencatatan keuangannya serta laporan progres kegiatan pemasaran serta manajemen inventory yang sudah di lakukan apakah sudah on track atau belum.

Pelatihan ini bertujuan agar para anggota Karang Taruna khususnya pada Rw 11, Kelurahan Pengasinan, Kota Depok, Provinsi Provinsi Jawa Barat membuka mindset tentang pentingnya pengembangan Sumber Daya Manusia (SDM). Karang Taruna sangat penting dimana Karang Taruna merupakan salah satu tempat untuk mencetak pemuda yang madani dan kreatif mampu memberikan manfaat kepada masyarakat melalui peranannya menjadi pilar-pilar kesejahteraan sosial, menjadi mitra kerja pemerintah melalui usaha kewirausahaan.

Berikutnya adalah agar dapat lebih memahami tentang berwirausaha UMKM yang baik dan benar, melakukan pencatatan keuangan sederhana dengan baik sehingga dapat diketahui arus kas masuk dan keluar, memahami tentang manajemen inventory dan pengaturan bahan baku, mengevaluasi tentang promosi, cara pemasaran yang kreatif, inovatif dan efektif dengan biaya yang murah serta memotivasi menumbuhkan jiwa enterpreneur bagi anggota yang belum aktif bergabung sehingga dapat menciptakan peluang usaha yang lebih bernilai ekonomis. 


\section{HASIL DAN PEMBAHASAN}

Kegiatan Pengabdian Kepada Masyarakat (PKM) Dosen Universitas Pamulang di Kelurahan Pengasinan RW 011 adalah untuk membina para anggota Karang Taruna serta memberikan pelatihan pembukuan sederhana bagi entrepreneur muda dilingkungan Kelurahan Pengasinan RW 11. Dimana sekarang mereka sudah melakukan produksi barang konsumsi seperti minuman dan makanan snack, mereka juga sudah berhasil memasarkan atau menjual kepada masyarakat dilingkungan RW namun belum di lakukan pencatatan dalam pembukuan kas, sehingga mereka tidak mengetahui secara persis berapa modal yang sudah di keluarkan dan berapa keuntungan yang sudah di perolehnya. Melalui pembukuan ini kita dapat melihat kondisi keuangan bisnis, keuntungan, kerugian, dan lain sebagainya dalam usaha yang kita jalankan.

Hal berikutnya yang dilakukan oleh kami para Dosen Universitas Pamulang yang akan melakukan Pengabdian Kepada Masyarakat (PKM) kali ini di Kelurahan Pengasinan RW 11 adalah dalam pelatihan Manajemen Pemasaran bagi entrepreneur muda dilingkungan Kelurahan Pengasinan RW 11. Pemasaran merupakan salah satu fungsi dari perusahan disamping fungsi lainnya dalam mengelola perusahaan seperti keuangan, produksi dan personalia. Semua pebisnis selalu menginginkan perkembangan usaha cepat dan dapat bertahan dalam persaingan yang keras. Promosi produk yang baik merupakan cara paling efektif untuk memasarkan produk atau jasa layanan, terutama pemilik UKM harus mengetahui pentingnya strategi promosi dan pemasaran.

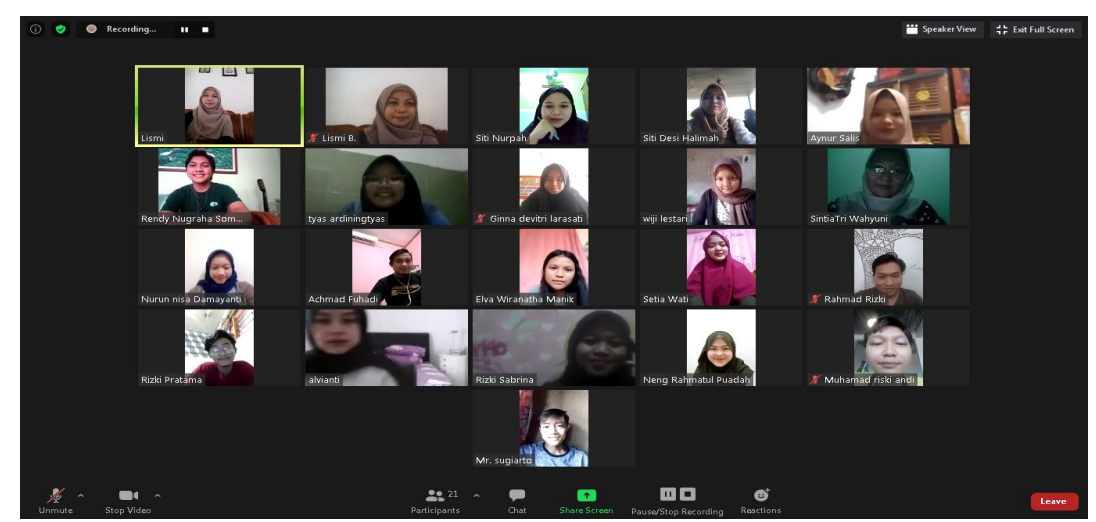

Gambar 1. Pembukaan PKM secara Daring

Dengan manajemen yang baik maka akan diperoleh laba yang jelas jumlahnya dan akan terjadi pengambilan keputusan yang tepat. Dengan demikian, laporan pembukuan sederhana sangat penting diperlukan dan diterapkan oleh pelaku usaha dan tidak menggabungkan uang pribadi dengan usang hasil usahanya. Manajemen keuangan usaha kecil pada dasarnya tidak terlepas dari fungsi manajemen itu sendiri yang meliputi kegiatan perencanaan, pengorganisasian, pelaksanaan dan pengendalian serta evaluasi.

Kami dari dosen Team Pengabdian Kepada Masyarakat Universitas Pamulang akan selalu memberikan pendampingan, mentoring atas kendala serta memberikan solusi yang terbaik atas permasalahan yang terjadi selama berlangsungnya kerjasama sehingga tujuan untuk mengurangi pengangguran di RW 11, Kelurahan Pengasinan, Kota Depok, Provinsi Jawa Barat dapat terwujud sesuai dengan target kerja. 


\section{KESIMPULAN DAN SARAN}

Dari pelaksaan tahap awal kegiatan Pengabdian Kepada Masyarakat ini dapat disimpulkan beberapa hal antara lain yaitu :

1. Membuka mindset tentang pentingnya pengembangan Sumber Daya Manusia (SDM) Karang Taruna sangat penting dimana Karang Taruna merupakan salah satu tempat untuk mencetak pemuda yang madani dan kreatif mampu memberikan manfaat kepada masyarakat melalui peranannya menjadi pilar-pilar kesejahteraan sosial, menjadi mitra kerja pemerintah melalui usaha kewirausahaan.

2. Pelatihan pembukuan keuangan sederhana, manajemen inventory, promosi dan pemasaran yang efektif dan inovatif bagi para anggota Karang Taruna Rw 11 Kelurahan Pengasinan menguggah semangat mereka sebagai generasi muda dan entrepreneur muda yang baru memulai bisnis untuk lebih tertib dan disiplin dalam manajemen usaha mereka.

3. Pengertian tentang teknologi terbaru yang dapat digunakan untuk membantu efisiensi kinerja mereka. Karena perkembangan industri ekonomi kreatif tidak terlepas dari ecommerce, tidak hanya dari segi peralatan namun juga dari segi pemasaran seperti contohnya membawa UMKM ke dunia digital yang sedang marak di masyarakat saat ini sehingga usaha lebih dikenal oleh masyarakat. UMKM di Indonesia mulai banyak merambah ke dunia digital seperti e-commerce dan marketplace. Ini adalah wadah bagi pemilik UMKM untuk memaksimalkan usaha dan potensi kreatifitasnya. Optimasi penggunaan e-commerce dan media sosial dapat dilakukan agar UMKM mereka dapat berkembang lebih pesat lagi.

Mengingat besarnya manfaat kegiatan Pengabdian Kepada Masyarakat ini, maka selanjutnya perlu di lakukan beberapa hal antara lain :

1. Mengadakan sosialisasi dan pelatihan serupa pada anggota Karang Taruna atau organisasi pemuda lainnya seperti komunitas-komunitas UMKM lainnya di tingkat Kelurahan ataupun Kecamatan yang lain, dengan materi yang serupa.

2. Adanya kesinambungan program pasca kegiatan Pengabdian Kepada Masyarakat ini sehingga para peserta benar-benar dapat mempraktekkan atau mengaplikasikan materi, pengalaman dan pengetahuan yang sudah di berikan sehingga dapat langsung di rasakan hasilnya dan dilakukan perbaikan jika terjadi kendala saat pelaksanaan.

3. Adanya komitmen dari semua pihak untuk membantu dalam memberikan strategi promosi pemasaran produk yang dihasilkan dengan cara yang efektif dan efisien serta lebih tepat sasaran sehingga dapat membantu mempercepat perputaran keuangan dan stock mereka.

\section{DAFTAR PUSTAKA}

Assauri, Sofjan. (2013), Manajemen Pemasaran Dasar, Konsep, Dan Positioning, Jakarta:PT. Radja Grafindo Persada

Buchari Alma. (2013), Manjemen Pemasaran Dan Pemasaran Jasa, Bandung:Alfabeta.

Cristiani D. Manengal (2015) Pengaruh Kualitas Layanan, Kualitas Produk Dan Penetapan Harga Terhadap Keputusan Pembelian Pada Cv. Esa Genangku (Esacom) Manado (X1) Kualitas Layanan (X2) Kualitas Produk (X3) Penetapan Harga (Y) Keputusan Pembelian Analisis Regresi Linier Berganda Kualitas Layanan, Kualitas Produk, dan Penetapan Harga secara bersama-sama berpengaruh positif dan signifikan terhadap terhadap Keputusan pembelian. 
Effendy, A. A., Mas'adi, M., Wicaksono, W., Nurhadi, A., \& Murtiyoko, H. (2020). "Mewujudkan Generasi Muda Yang Unggul Di Era Globalisasi Dengan Berbekal Ilmu Wirausaha Yang Kreatif, Inovatif Dan Diferensiatif Pada Remaja Masjid Al Hikmah Reni Jaya Pamulang Tangerang Selatan.” Jurnal Pengabdian Dharma Laksana, 3(1), 815.

http://repository.stiewidyagamalumajang.ac.id/566/3/Bab\%202_watermark.pdf diakses pada 2 Januari 2021, pukul 08.15 WIB

https://repository.widyatama.ac.id/xmlui/bitstream/handle/123456789/8103/Bab\%202.pdf diakses pada 2 Januari 2021, pukul 10.22 WIB

http://digilib.unila.ac.id/6229/16/BAB\%20II.pdf diakses pada 2 Januari 2021, pukul 11.34 WIB

Iskandar, Putong. (2010), Economics Pengantar Mikro \& Makro, Jakarta:Mitra Wacana Media

Kotler, Philip dan Amstrong (dalam Priansa). (2017), Manajemen Pemasaran. Edisi tiga belas Bahasa Indonesia. Jilid 1 dan 2. Jakarta:PT. Erlangga.

Kotler, Philip dan Gary Amstrong, (2014). Dasar-dasar Pemasaran. Edisi Kesembilan Jilid Satu. Jakarta:PT. Indeks Kelompok Gramedia.

Kotler, Philip, (2013), Manjemen Pemasaran, Edisi kedelapan, Jakarta:Salemba Empat

Samuelson, P.A, Putong. (2013), Peluang Usaha, Jakarta:PT. Erlangga

Sashi, C.M. (2012). "Customer engagement, buyer-seller relationships, and social media". Management Decision, Vol. 50 Iss: 2, pp.253-272.

Sunyoto, Danang. (2013), Teori Kuisioner dan Analisis Data untuk pemasaran dan perilaku konsumen, Jakarta:Graha Ilmu

Suryana, Kewirausahaan Full Edision (2013), Jakarta:Salemba Empat.

Vivek, S. D., Beatty, S. E., \& Morgan, R. M. (2012). Customer Engagement: Exploring Customer Relationships beyond Purchase. Journal of Marketing Theory and Practice, vol. 20, no. 2, pp. 127-145. 